\title{
UMA IMAGEM DE MULHER \\ no romance Atire em Sofia, de Sonia Coutinho
}

Rosana Ribeiro Datrício

\section{ESCOLHAS (E CULPAS) DE SOFIA}

Atire em Sofia ${ }^{1}$, editado em 1989 e anunciado como primeiro romance de Sônia Coutinho, retoma o tema da volta às origens já trabalhado em O Jogo de Ifá, e se constrói pelo processo de colagem das memórias dos personagens.

A história envolve um grupo de jovens amigos, os acontecimentos e o sentido de suas vidas que são focalizados de maneira avaliatória. O romance agencia as várias vozes dos personagens implicados, que comparecem com suas opiniões e interpretações sobre si e os outros. Nesse processo, as experiências vividas afloram à consciência dos personagens e, através da colagem de suas memórias, o enredo toma forma e se desenvolve como um diálogo entre o presente e o passado.

$\mathrm{O}$ nome da personagem, Sofia, é muito expressivo devido, sobretudo à carga de simbolismo: significa a Sabedoria que, segundo ressalta Madonna Kolbenschlag, nomearia, a partir dos ensinamentos de Jacob Boehme (1575-1624), um princípio feminino de "um ser incondicionado, coexistente com a deidade masculina criadora", de acordo com a tradição gnóstica. ${ }^{2}$ Em Atire em Sofia, pode-se admitir a hipótese de que a autora pretendeu criar uma personagem feminina que neutralizasse as diferenças entre os sexos, assumindo atitudes e privilégios normalmente reservados ao sujeito masculino.

O nome da protagonista remete também, de imediato, à referência ao romance de William Styron, A Escolha de Sofia, ${ }^{3}$ em que a personagem, uma polonesa capturada 
pelos alemães, é separada dos filhos no momento da triagem e é obrigada a fazer uma escolha dramática. Com qual dos filhos ela escolheria ficar? Pressionada e sob ameaça de perder ambos os filhos, entre Jan e Eva, ela escolheu o menino Jan, e se consumiu em remorsos até o fim de sua existência pelo peso de sua escolha capital. No romance de William Styron, o conflito interior da personagem resulta numa história pungente e emocionante, que deixa o leitor perplexo diante de situações humanas dramáticas causadas por uma guerra.

Guardadas as devidas proporções em termos de dramaticidade, a personagem de Sônia Coutinho também faz uma escolha capital. Entre manter um casamento insosso, convencional, e criar as duas filhas, ela preferiu romper, abandonar as convenções sociais, e tentar uma vida própria no Rio de Janeiro. No entanto, ela amarga as várias conseqüências decorrentes de sua decisão, entre as quais o remorso por haver deixado as filhas para trás. Ao reencontrá-las, anos depois, defronta-se com o mutismo e a indiferença, o que lhe acentua o forte sentimento de culpa e a necessidade de se justificar:

Sinto necessidade de me justificar outra vez, como venho fazendo há anos, de dizer que era a minha chance, se não tivesse saído naquele momento seria tarde demais, era o prazo limite para escapar daquele esquema sufocante, para tentar conhecer a vida fora da redoma de minha família, viver uma experiência humana mais ampla, integral. Terei conseguido? Será que valeu a pena? Já não sei mais o que eu esperava, quando saí daqui. (AS, p. 28)

Sofia experimenta o dilema muito discutido nos anos da emancipação feminina: procurar realização no casamento e se acomodar dentro das convenções ou partir para uma nova vida, sozinha, ou com a possibilidade de manter relacionamentos não convencionais, preservando a liberdade. Na segunda situação, como foi o caso da personagem, a mulher que se quer liberada tinha de enfrentar os preconceitos e as sanções impostas pela sociedade como, por exemplo, a perda da guarda dos filhos e da pensão do ex-marido. Isso se explica pelo fato de haver um conceito estipulado sobre o papel da mulher casada que deve amoldar-se às convenções, como assevera Belkis Morgado:

Ser mulher, dentro de um conceito geral, significa ser feminina, virtuosa, trabalhadora, meiga, dócil - todas essas características levando ao papel predeterminado do que a sociedade chama com muito orgulho de "rainha do lar". 4 
Sofia não aceita o rótulo e estabelece a ruptura com o modelo tradicional. Opta pela situação similar àquela vivida pela protagonista do conto Uma certa felicidade, mulher que também faz uma opção incompreensível aos olhos daqueles que lhe prefiguram, de forma conservadora, um “destino de mulher":

Eu era inquieta, tinha ambições. Pensava em pintar, em levar uma vida livre e independente, coisas que li nos livros e revistas. Apesar da boa situação em que eu vivia, com minha família, dos planos que fazia com meu noivo, encontrei um homem, apaixonei-me, resolvi largar tudo e vir com ele para o Rio. ${ }^{5}$

Ambas as personagens representam a mulher no limite da superação dos condicionamentos e valores do passado, pois fazem uma escolha polêmica, envolvidas pela atmosfera de ruptura, o que as torna sujeitas a arrependimentos ou a futuras culpas. $\mathrm{O}$ sentimento de culpa ${ }^{6}$ de Sofia a acompanha até o fim. A protagonista conserva sempre uma dúvida atroz sobre haver tomado ou não a melhor decisão. As dúvidas tornam-se parte da insegurança com que a personagem avalia sua trajetória de vida. Ao mesmo tempo em que se culpa, ela se pergunta até que ponto desejaria realmente conviver com as filhas: "Será que em certa medida, não está mentindo, não desejava também, o tempo todo, sentir-se inteiramente livre e disponível?” (AS, p. 28).

Sem encontrar resposta, Sofia segue o seu caminho labiríntico, procurando justificar-se a cada passo e avaliando o peso de sua decisão. A visão crítica em relação ao papel da esposa submissa e subalterna ao marido, cujo exemplo expressivo é sua própria mãe, é um elemento sempre presente em sua reflexão. A protagonista tem consciência de que se encontra numa posição crítica, em que se destaca pelo fato de haver rompido com a tradição da família e enfrentado as conseqüências do ato que a deixa marcada pelo resto da vida. Ela resolve ficar sozinha, após alguns relacionamentos que poderiam ser duradouros. Mas considera a solidão um tesouro duvidoso nos momentos de fragilidade:

Claro que poderia, se tivesse feito as necessárias concessões, diz agora a si mesma, estirada na cama, ter ficado pelo menos com alguns daqueles homens que passaram por sua vida. Se não ficou, pensa, foi porque achou preferível, de alguma forma, continuar sozinha. (AS, p. 29)

Sofia experimenta a tensão entre a possível decisão e as condições repressoras em que vive. Assume uma decisão, optando livremente pela ruptura do meio familiar 
No entanto, Sofia não é totalmente livre, pois há uma marca de fatalidade em seu necessário retorno à cidade de origem para se justificar e de alguma forma atenuar uma culpa constante. Segundo Marilena Chauí:

A liberdade é a capacidade para darmos um sentido novo ao que parecia fatalidade, transformando a situação de fato numa realidade nova, criada por nossa ação. Essa força transformadora, que torna real o que era somente possível e que se achava apenas latente como possibilidade, é o que faz surgir uma obra de arte, uma obra de pensamento, uma ação heróica, um movimento anti-racista, uma luta contra a discriminação sexual ou de classe social, uma resistência à tirania e a vitória contra ela. ${ }^{7}$

Essa concepção de liberdade pressupõe uma ruptura sem volta, sem que se olhe para trás. Para romper é necessário ter muita consciência acerca dos objetivos a serem alcançados. Apesar de haver tentado se desvencilhar de uma situação opressiva, a personagem não alcança totalmente a liberdade, pois continua presa ao passado através do sentimento de culpa. Por isso houve a necessidade de voltar às origens, como a cumprir um destino fatal, apesar de possuir senso crítico acerca dos papéis femininos predeterminados. Em sua reflexão, a personagem mostra uma visão crítica que se opõe ao casamento já que o considera uma forma de anulação da mulher. As relações familiares tradicionais são vistas como "longos exercícios de ódio", com a manutenção das aparências, o que ela repudia com veemência:

Os casamentos aqui, na geração da minha mãe, eram longos exercícios de ódio. A mulher deveria permanecer sempre criança, para agradar e servir sempre ao homem. [...] Gerações inteiras de mulheres de que não temos nenhuma notícia, de cuja vida não ficou registro nenhum. [...] Mulheres que até se desabituaram de dizer "eu sou”, "eu quero". (AS, p. 50)

A reflexão de Sofia contraria e desmitifica a idéia patriarcal em torno do eterno feminino ${ }^{8}$, que postula a realização da mulher através da idéia de amor entendido como sinônimo de entrega, doação e devotamento, numa situação em que ela abdica de sua individualidade e aspirações próprias para dedicar sua vida ao marido e à criação dos filhos. A valorização e a aceitação social da mulher passavam, portanto, pela aferição de seu papel no seio da família burguesa, constituída em bases conservadoras. Sofia optou pelo caminho contrário, afrontando todo um código imposto a gerações e gerações de mulheres. Diante de situações prefiguradas, a sua atitude se converte em transgressão a um modelo, afirmando-se como uma escolha difícil e problemática. 
Na era da emancipação da mulher, com a crise dos valores antigos, tornam-se recorrentes os casos de escolha problemática. Essa situação também está presente na ficção de Clarice Lispector, a exemplo do romance $A$ paixão segundo $G H .^{9}$ A protagonista rememora uma situação traumática de opção capital, em que decidiu fazer um aborto, numa atitude que fere o conceito conservador de maternidade. Quando relembra tal fato, apesar de o aborto ser resultado de uma decisão consciente, sente o peso da decisão e assume a certeza da perda que sua escolha exigiu. Primeiro vem a lembrança do momento em que decidira fazer o aborto. Logo adiante, a consciência da perda acarretada pela própria decisão tomada, que transforma o momento da escolha num drama a ser revivido durante toda a vida: "Eu me havia livrado do deserto, sim, mas também o perdera! E perdera também as florestas, e perdera o ar, e perdera o embrião dentro de mim." (PSGH, p. 97)

No romance de Clarice Lispector, a personagem G.H. abre mão da maternidade, uma atribuição feminina, de forma consciente. No entanto, ela não consegue se libertar da sensação de perda inerente a sua decisão. Essa dialética em torno da escolha que implica em ganho pessoal, em termos de liberação, mas também impõe uma perda, segundo a lógica da maternidade exemplar, permeia a condição feminina nos romances citados. Geralmente, a escolha que leva a uma liberação entendida como um avanço pessoal da mulher, ocasiona também uma perda. A situação resultante leva as personagens a um conflito que se converte num processo recorrente de autoquestionamento. Sem dúvida, o teste é penoso e requer maturidade e força de espírito. A dificuldade está em decidir sem sucumbir ao peso das culpas e sabendo evitar as complicações psicológicas decorrentes dos arrependimentos.

A personagem de Sônia Coutinho, também consciente das perdas inerentes à sua escolha, procura justificar, mais para si própria do que para os outros, a sua atitude transgressiva. Uma das conseqüências de sua decisão é o afastamento das filhas e a solidão atual que Sofia interpreta de forma dual: ora seria um tesouro duvidoso, ora poderia transformar-se em pânico e desamparo. Noutros momentos, sua solidão adquire um sentido muito forte de protesto, como revela num diálogo com um de seus amigos:

Minha solidão não é de brincadeira. Talvez seja uma solidão política, por assim dizer. Um protesto, uma defesa. Sou solitária por não ter feito concessões, eu sei, por não ter entrado no esquema nem atendido ao modelo. Mas o resultado é solidão mesmo, sem apelação. (AS, p. 162-163)

Sofia era insubmissa às normas impostas à mulher, que eram bastante rígidas no ambiente social de sua cidade de origem. Possuía uma personalidade instável e in- 
quieta que se chocava com a idéia convencional do casamento, ou da vida feminina predominantemente voltada à rotina de afazeres domésticos em condição submissa ao marido. Em diálogo com Fernando, ela fala da experiência de seu segundo casamento, com Jacinto:

- Saí machucada do meu segundo casamento. Depois, fiz algumas experiências. Só queria me divertir, sabe? Tenho um lado masculino que exerço de maneira muito consciente, não quero gravitar em torno de ninguém, faço questão de ser a dona do meu nariz. Essa disponibilidade me agrada à beça, o que não quer dizer que, às vezes, não seja terrível. Como sempre acontece, aliás, com relação a tudo. (AS, p. 84)

O fato de considerar essa sua independência como uma característica masculina reforça a idéia de que o poder de ser independente e viver a própria vida é inerente ao homem, que se casa, tem filhos, mas não deixa de ter uma profissão e realização de planos de vida que independem das relações na família. Reforça a idéia de que o casamento pode travar, de alguma forma, a realização da mulher. De posse dessa certeza, Sofia vai se colocar ao lado de outras personagens que se notabilizaram por adotarem uma postura transgressiva. Uma dessas personagens é Lilith, a mitológica companheira inicial de Adão, que seria o protótipo da mulher que se recusa a submeter-se às regras impostas pela norma:

Eu, Lilith. A primeira companheira de Adão, a mulher suja de sangue e saliva que lhe perguntou: "Por que devo me deitar embaixo de você? Por que devo me abrir debaixo do seu corpo? Por que ser dominada por você? Mas eu também fui feita de pó e por isso sou sua igual. (AS, p. 12)

Trata-se de uma citação direta, que estabelece uma relação intertextual entre a personagem Sofia e a lenda de Lilith, relacionando-as a partir das respectivas atitudes transgressivas. ${ }^{10}$

Outra associação mitológica constrói-se na narrativa, mediante relação da protagonista com Iansã ou Oiá: a caracterização da personagem é feita de acordo com os atributos da entidade afro-brasileira, como uso de roupas em cores vermelha e branca e definição de uma natureza pessoal guerreira. ${ }^{11}$ Além disso o tempo chuvoso presente no verão, considerado pelo personagem Fernando como verão esquisito, constitui um prenúncio dos acontecimentos vindouros e a protagonista, em diálogo com Tetu, explica que as chuvas de Iansã representam o lamento da entidade por todas as mulheres: 
- Iansã está chorando, isto sim, por muitas mulheres, gerações inteiras de mulheres que foram espezinhadas nesta cidade e nunca puderam protestar. (AS, p. 44)

Naturalmente que ela se refere aos muitos anos de opressão sofrida pelas mulheres de várias épocas, que, sem direito ao protesto, tiveram que se submeter caladas ao poder patriarcal. Aquelas que transgrediam as normas eram severa e exemplarmente punidas. A chuva de verão representa um lamento que é também protesto histórico.

O texto do romance é permeado de prenúncios, estabelecendo a marca da fatalidade, da qual a personagem não poderia escapar, desde que resolvera voltar à sua cidade de origem:

A humilde certeza da morte, uma verdade que vê em cada rosto. Quase em paz, a morte na cidade descarnada pelo sol, desfeita pela chuva, cidade onde as frutas amadurecem depressa demais, oferecendo sua perecível polpa.

Então, foi por isso que voltou, descobre agora, ouvindo essa vaga musiquinha, era preciso que aprendesse a morte. Como um dia se aprende a velhice, mesmo sem querer, estabelecendo à revelia os próprios elos do tempo. (AS, p. 90)

Está presente nessas passagens o prenúncio de que a morte de Sofia era inevitável. E o seu retorno à cidade não representaria a recuperação das perdas, mas sim um aprendizado para a morte. De fato, a protagonista busca uma saída para seus impasses existenciais inerentes à sua culpa, mas não encontra respostas positivas nas filhas, nem no trabalho com teatro que aparentemente foi a justificativa de sua volta. Envolvida com suas reflexões em busca dos sentidos de seu retorno, a personagem na verdade vai tomando consciência de sua temporalidade e finitude. Diante dessa certeza segue a sua trajetória de forma humilde e consciente:

Viver e morrer são a descoberta da finitude humana, de nossa temporalidade e de nossa identidade: uma vida é minha e minha, a morte. Esta, e somente ela, completa o que somos, dizendo o que fomos. Por isso, os filósofos estóicos propunham que somente após, quando terminam as vicissitudes da vida, podemos afirmar que alguém foi feliz ou infeliz. Enquanto vivos, somos tempo e mudança, estamos sendo. ${ }^{12}$ (Grifos da autora).

Exatamente por este motivo é que Fernando rememora a vida de Sofia de maneira nostálgica. $\mathrm{Na}$ lógica do enredo, a morte dela é fator necessário para que ele 
recupere o passado e faça uma espécie de avaliação da vida da amiga e do significado de sua morte. $\mathrm{O}$ desenrolar dessas reflexões dá-se enquanto ele folheia o álbum de fotografias e percebe que a morte de Sofia não foi praticada por uma única mão, e sim por várias:

Examina outra vez o álbum de fotografias que tem no colo, detém-se na foto de Sofia, já um rosto de época, com sua maquilagem pesada, sobrancelhas muito grossas, obvia-mente pintadas a lápis. O gatilho da arma assassina, pensa, foi apertado por muitas mãos. E o alvo daqueles três tiros não era exatamente Sofia, sua pessoa física, mas o que ela representava, seu desafio. (AS, p. 114)

A morte de Sofia é simbólica, pois representa a tentativa que faz a sociedade conservadora de eliminar o seu ideal de vida e a sua busca de liberdade. A trajetória da personagem representa o desafio que a sua geração enfrentava e que a sociedade conservadora desejava eliminar. O próprio Fernando se pergunta se também não ajudou a matar Sofia. Ele, um homem de classe média, acomodado e bem situado, jamais ousara questionar os valores convencionais. Ele sentia-se também incomodado pela protagonista que rompera, que transgredira e subvertera, com seu exemplo, a ordem estabelecida.

\section{A PUNIÇÃO DE SOFIA: TRANSGRESSÃO/MALIGNIDADE}

Ao final de suas reflexões, Fernando usa a imagem bíblica da destruição para interpretar o fim trágico de Sofia:

Sofia cometeu um erro fatal, conclui Fernando agora, quis olhar para trás quase vinte anos depois. E os dois anjos de Jeová, enviados para destruir Sodoma e Gomorra, já haviam recomendado a Lot que, ao partir com a família, não tentasse ver o que estava deixando. Como a mulher de Lot não resistiu, foi transformada em estátua de sal, por seu apego a uma cidade condenada à ruína. (AS, p. 115)

Não resta dúvida que essa correlação feita por Fernando enfraquece a posição da protagonista, uma vez que considera a sua volta às origens um erro fatal, um olhar para trás que a leva à ruína. Mas, a seu modo, o narrador também se comporta como a mulher de Lot. Ele lança seu olhar para trás, lembrando Sofia, de sua trajetória transgressora, como uma personagem condenada de forma inapelável. Assim, o romance adquire um caráter pessimista, pois deixa entrever que a sociedade e a própria 
mulher ainda não têm condições de conciliar os novos papéis femininos com a estrutura familiar vigente, o que gera conflitos de conseqüências trágicas. Essa tensão é reforçada pela passagem em que Fernando correlaciona o terror da morte representado pelo mitológico Cérbero à situação da protagonista, indicando a fatalidade do seu destino, através da seguinte imagem:

Certa tarde, enquanto conversavam e bebiam, num bar à beira-mar, viu ao lado dela o cão de Hades, Cérbero - cinqüenta cabeças, cauda de dragão, pescoço e dorso eriçado de serpentes. A encarnação do terror e da morte, personificação dos infernos e do inferno de cada um. (AS, p. 79) $)^{13}$

Outro recurso que reforça o caráter transgressivo da personagem é a sua transformação em bruxa numa noite de inquietação:

Segue rumo à periferia da cidade e, lá do alto, vê nas estradas grupos de pessoas que caminham todas na mesma direção. Baixa o vôo, procura descobrir alguma encruzilhada onde exista uma árvore apodrecida, uma coruja, um jumento um porco ou uma cabra - os animais que indicam o local de um sabá. (AS, p. 93-94)

Avista, afinal, um tronco oco e uma coruja e vê que, nas proximidades o círculo já está formado. Desce e, quando chega, mistura-se com mulheres que pulam e gritam, os seios descobertos. Bruxas acocoradas respondem, também aos gritos. Logo chega o demônio, sob a forma de um bode, mas imediatamente se transforma em gato. (AS, p. 94)

Observe-se que se trata de uma reunião feminina, presidida pelo demônio, figura inscrita na cultura antiga como poderoso elemento masculino. Jean-Michel Sallmann informa que o Ocidente conservou no seu imaginário a convicção de que a prática da feitiçaria maléfica e demoníaca estava intimamente ligada à natureza feminina. Este estereótipo, que remonta ao século XIV, faz parte do imaginário popular e se transforma num dos assuntos principais da Inquisição, até o século XVII. ${ }^{14}$ Naquela época, quando não havia respostas para determinados fenômenos, muitas vezes naturais, como mortes, doenças, catástrofes, a sociedade procurava atribuir a culpa a alguém. Os nomeados bruxos ou, em sua maioria, bruxas, geralmente mulheres idosas e sozinhas, eram os alvos dessas acusações. Acusadas de praticarem culto demoníaco, eram, via de regra, punidas com a morte pelo fogo. Segundo se acreditava, somente assim a sociedade ficaria livre do mal que essas pessoas representavam. As crenças nas seitas de bruxos e a aproximação da mulher à bruxaria são criações do imaginário popular. A Inquisição, o tribunal religioso católico, tinha por atribuição caçá-las, julgá-las e condená-las pela prática de um crime imaginário. Assim explica Jean-Michel Sallmann: 
O estereótipo da feiticeira maléfica e satânica nasceu da crise que atravessou a cristandade no final do século XIV e que se tornou mais profunda com a ruptura da unidade religiosa no século XVI. Este modelo, que se impõe na ideologia dominante, disfarça mal uma grande diversidade de crenças. Apesar disso, ele sanciona uma degradação da imagem social da mulher no final da Idade Média. ${ }^{15}$

Embora situando-o em nível simbólico, o texto de Sônia Coutinho atualiza este estereótipo negativo atribuído à condição feminina. Nele, há uma recorrência dos antigos Sabaths ou sinagogas, sob o comando do demônio. O mito demonológico, ou seja, "a crença na existência de uma seita de feiticeiros voltados ao culto do Diabo, crença que se constitui no final do século XIV."16 Um dos elementos emblemáticos dessa crença seria o chamado "beijo obsceno", que também está referido no texto de Sônia Coutinho:

Mais tarde, terminam de comer, começa uma grande orgia. O demônio chama a si todos os presentes, um de cada vez, e pedem que o beijem. Quer o beijo diabólico, o beijo obsceno. (AS, p. 94)

Em ensaio sobre o tema, Emanuel Araújo refere-se ao elemento fantástico presente nesses relatos relacionados aos sabaths:

[...] Reuniões em que as feiticeiras entregavam-se ao Diabo em cópulas fantásticas que começavam sempre com a mulher beijando o "vaso traseiro" ou "vaso imundo" de seu senhor espiritual, que para tanto levantava sobranceiro a cauda. ${ }^{17}$

Adiante, o ensaísta refere-se ao poeta Gregório de Matos, que escreveu um poema aludindo a esta crença:
Dormi com o Diabo à destra
e fazei-lhe o rebolado, porque o mestre do pecado
também quer a puta mestra,
e se na torpe palestra
tiveres algum desar,
não tendes que reparar,
que o Diabo quando emboca
nunca dá a beijar a boca,
e no cu o heis de beijar. ${ }^{18}$ 
Trata-se de uma referência direta ao ritual do beijo obsceno. O ponto chave é que essas reuniões são regidas por um elemento masculino e referendadas por uma roda feminina, colocando a mulher mais uma vez em posição secundária e de servidão.

Nesse mesmo campo, ocorre também uma associação com a presença do gato, enquanto elemento ligado ao culto satânico. Isso sublinha a idéia de malignidade do animal, presente no romance, além de reforçar a imagem da protagonista circunscrita ao espaço do socialmente proibido, considerado ilícito ou nocivo.

Outro indício que reforça esse cunho fatalista é a experiência da invisibilidade vivida pela personagem, que pode ser entendida como uma crise de identidade, associada com a visão de inúmeros gatos que invadem o seu apartamento:

Mas, de repente, como se atendessem a um silencioso aviso, os gatos todos, que já cobriam a sala e o seu corpo, voltam para a cozinha, comprimindo-se uns contra os outros, e desaparecem inexplicavelmente, enquanto Sofia agora se levanta, caminha pelo apartamento vazio, vai até sua escrivaninha, num dos quartos, pega um cigarro e o acende, tentando, mais uma vez, lembrar sua identidade perdida, depois de alguns dias sem rosto. (AS, p. 122-123)

Segundo Jean Chevalier os gatos, de uma forma geral, possuem uma simbologia complexa, ora são vistos como benéficos, ora como maléficos, o que se justifica pela atitude ao mesmo tempo amistosa e dissimulada do animal. ${ }^{19}$ No romance, eles são coadjuvantes da representação de Sofia como personagem transgressiva. Este ponto de vista se sustenta pela idéia de malignidade que pode ser associada ao gato, como advertem Chevalier e Gheerbrant, afirmando que "tanto na Cabala como no Budismo o gato é associado à serpente: indica o pecado, o abuso dos bens deste mundo. Neste sentido, o gato é por vezes representado aos pés de Cristo.” ${ }^{20}$

No romance em análise, essa visão pode indicar que a protagonista, por se colocar à margem dos padrões estabelecidos, corria um perigo mortal. Isso também sinaliza para o fato de que ela não poderia aspirar ao equilíbrio, pois a sua decisão do passado resultara numa profunda crise de identidade. No limite, a imagem onírica dos gatos seria um mau presságio para a protagonista.

A invisibilidade que em seguida atinge Sofia é simbólica e representa o seu afastamento gradual do mundo dos vivos. A personagem sente-se intimidada diante dessa situação e reflete sobre a sua virtual morte e as experiências de final de vida que presenciara:

E agora, assim invisível, estaria morta? Será que a invisibilidade era a morte? Teria entrado em estado de fantasma? (AS, p. 125). 
A crise de identidade e o medo de morrer provocam este sobressalto em Sofia, reforçado quando a personagem relembra o falecimento da avó, da sua velha empregada e de Josué, um dos amigos presentes no álbum de fotografias de Fernando. Todas essas experiências, umas mais dolorosas do que outras, serviram para conscientizar a protagonista acerca dos sentidos desse "ritual". Isto funciona como uma preparação necessária, já que a nossa cultura não nos coloca em intimidade com a morte. Há todo um mistério a cercá-la e Sofia tinha consciência do seu despreparo, tal como a consciência acerca do seu momento final. $\mathrm{O}$ seu retorno à cidade tinha uma ligação com a proximidade da morte, em cumprimento de um destino já determinado:

Mas, de repente tranqüila, neste fim de tarde em esparso cinza, então pensa que entende, afinal, a lição da cidade - a de que vai ter de morrer. A dádiva da cidade, o aprendizado da morte, sua sedução. (AS, p. 90)

A morte é vista como uma experiência inevitável a todos, mas que precisa ser devidamente aprendida. Dessa maneira o caráter fatalista de sua própria morte é assimilado passivamente pela protagonista.

\section{A VIDA REVISTA: AS RELAÇÕES CONFLITUOSAS}

Sofia assume o seu aprendizado da morte passando em revista o seu passado. Fatos marcantes são revisitados e passados em revista na mente da personagem. Entre estes, a lembrança do casamento com Pedro, que representara uma afronta para a sua mãe :

Lembra como ela ficou contrariada com seu casamento com Pedro, ele era moreno demais, quase mulato, o que o tornava inviável aos olhos de sua mãe, embora fosse rico. Mais tarde, quando vieram as filhas, continua a lembrar, a mãe afinal o aceitou, entrou em sua casa e estabeleceu um sólido vínculo com Pedro, que se tornou, afinal, um pacto contra ela. (AS, p. 138)

Em sua relação conflituosa com a mãe, Sofia encontra um aliado no marido, que a princípio não fora aceito. Fica no ar a pergunta: Sofia que enfrentou o casamento com Pedro, o fez por uma determinação íntima positiva ou por desafio à tirania da mãe? O casamento não durou, e nem preencheu o vazio existencial da personagem, apesar dos esforços nas sessões de análise com Sigmundo, o seu psicanalista. Sofia sentia atração pelo analista e por isso continuava a freqüentar o consultório. Quando percebeu que não seria correspondida, vingou-se abandonando as sessões: 
Estou soltando toda minha raiva em cima de você, toda a minha violência. Assim sem doçura nenhuma, querendo silenciar você. Distraída, provocante. Não sei se te silencio, mas irrito você, eu sei. Você se sente inseguro às vezes, não é? Enquanto eu, o tempo todo, queria era me apoderar de você, fingindo que não. Controlar você, como se fosse um títere, boneco meu, inteiro à minha disposição, para brincar. Fazendo você sofrer um pouquinho mas também lhe dando um amor imenso, como se fosse uma criança, o filho homem que eu não tive, como um garotinho. (AS, p. 58. Grifo nosso)

Percebe-se que Sofia propõe um jogo de sedução que encontra resposta no comportamento dissimulado do analista. Inicialmente, o princípio da cura pelo diálogo está desvirtuado nessa relação Sigmundo/Sofia, pois ambos estão desviados do objetivo, assumindo máscaras e subterfúgios. Ele aceita o jogo, mas foge no momento conveniente. Assim, faz valer a ética de não misturar vida amorosa com vida profissional, quando evita o envolvimento com sua paciente. No entanto, a protagonista continua o jogo e quer aprofundá-lo, esquecendo-se da relação profissional dele, analista, para com ela, paciente. Quando a personagem percebe que a sua sedução não foi persuasiva, vinga-se com um telefonema em que diz, sem convicção, que não mais irá às sessões, deixando claro que o tratamento não surtiu efeito. Com esse comportamento, tenta atingir os brios profissionais de Sigmundo.

Já o analista rejeitou a idéia de suprir as carências afetivas de Sofia, inclusive o seu desejo de ter um falo, um filho homem, tão estimulado pela cultura machista e assimilado pela protagonista. Aqui salta aos olhos uma contradição da personagem, já que ela tem uma história de rejeição aos valores preestabelecidos. A situação exigia necessariamente uma reflexão em torno de seus reais valores e o que ela considerava positivo ou negativo, para preservá-los ou rejeitá-los de acordo com as suas conclusões.

Ainda motivada pela necessidade de reflexão, Sofia relembra João Paulo:

E agora lembra João Paulo, um relacionamento já contaminado pela estranheza, por essa estranheza que, de forma crescente, impregna agora a cidade e sua vida. Volta para a rede, ouve mais um vez o ruído da chuva, caindo, porque chove, chove ainda, essa chuva de pânico e de lágrimas. (AS, p. 138)

Em simetria com as lágrimas de Iansã, Sofia desabafa através de um choro copioso, lamentando sua vida e suas escolhas:

Chora, chora e, quando afinal pára, sente na pele o vento que entra pela janela e lhe traz a cidade. Viscosa cidade, visco em tudo, na sensualidade pesada, em seu profun- 
do tédio sensual. No conselho que oferece, através de cada paisagem, cada rosto, cada objeto: "Não se esforce, não adianta. Desista, deixe-se ser". Um clima que faz as frutas apodrecerem depressa demais e ensina, para além de qualquer outra coisa, a morrer. Sua cidade esta, seu passado de beleza e horror. (AS, p.139)

A personagem associa a sua trajetória aos caminhos que a Cidade lhe aponta, uma atmosfera trágica, associando esse percurso com o apodrecimento das frutas. A personagem é também fruta que amadurece rapidamente, devido ao clima de insatisfação e insegurança que sente, ao lado do poderoso magnetismo do lugar que a atrai. Ela se sente como se estivesse impedida de buscar uma saída, como se houvesse um único caminho: o de vivenciar a proximidade da morte, para que soubesse reconhecêla e assim se preparar para o grande dia. Dessa forma, se estabelece um clima de morte anunciada, como se observa na fala de Pablo:

- Vim para te salvar, ou seja, para te levar embora. Estou captando uma aura estranha em torno de você. Não estou entendendo o que veio procurar aqui. (AS, p. 130)

Do ponto de vista da história, esta passagem funciona como mais um indício acerca do destino de protagonista, conferindo previsibilidade ao desfecho. Uma amiga de Sofia, chamada Linda, que se encontra de passagem pela cidade, também estranha a sua escolha de aí se fixar: "Não acredito que você vá ficar aqui" ( $A S$, p. 98). A narrativa mostra que Sofia se sentia presa a um destino fatal, como se não houvesse mais volta, pois tratava-se de algo inexorável pelo qual ela teria necessariamente de passar.

Como assinala Marilena Chauí, "a vida é uma experiência compartilhada.” Os seres trocam experiências, convivem, compartilham a vida. Enquanto isso, "morrer é um ato solitário, Morre-se só: a essência da morte é a solidão". ${ }^{21}$ Sofia, vive a experiência da preparação para a morte, e assim isola-se na sua solidão:

Tem a estranha sensação, às vezes, como nesse momento, de que foi tudo planejado, de alguma maneira, sem que ela soubesse - alguém a atraiu para cá, provocando aquele convite de trabalho num momento psicológico que não poderia recusá-lo. Tudo com uma finalidade que ainda não descobriu qual seja e não lhe parece animadora. Quem a trouxe, conclui, afinal, num lampejo, talvez tenha trazido também João Paulo. (AS, p. 98)

O enigma começa a ser desvendado e Sofia não só aprende, como tem o pressentimento do seu fim, com uma intimidade que incomoda ao extremo. É como se de 
alguma forma caminhasse para a morte, atraída por uma espécie de magnetismo. A relação com João Paulo começa a se caracterizar pelo estranhamento e pela certeza de que ele não estava bem. Há uma expressão de amargura e angústia que se mantém até o último momento, quando ele, já em estado de loucura, reproduz a cena da morte de Laura Luedi, tantas vezes planejada por ele no ato da escrita. Ao revelar para Sofia que quem havia matado a sua personagem tinha sido o jornalista João Paulo, o personagem-autor adianta o final do seu malogrado romance. Atualiza-se nesse momento o duplo Laura Luedi/ Sofia, quando João Paulo dirige para a amiga a pulsão de morte que projetava sobre a personagem de seu romance. Sofia torna-se, no plano da realidade ficcional, a protagonista do desfecho idealizado por ele:

Num último gesto, Sofia tenta puxar os lençóis, como se quisesse cobrir-se. Revive, num relance, amores, esperas, noites de ânsia, gritos de gozo e de dor, aviões, cidades estrangeiras, pessoas, encontros e desencontros, desco-bertas, livros, filmes, pores-de-sol, a estrela Vésper que ela, quando era menina, acordava todo dia de madrugada para procurar no céu e a frase final de uma empregada, que trabalhou a vida inteira para sua família: "Foi tudo bom, a vida é ótima." Em seguida vem o mar, vêm as águas, vem a volta ao útero do mundo. (AS, p. 177)

A morte de Sofia também representa um alerta às consciências sobre a situação da mulher na sociedade. É uma imagem feminina de uma geração que ficou clivada ${ }^{22}$ entre a educação recebida e o forte apelo da liberação feminina. Em nome dessa dialética, Sofia estabelece uma trajetória problemática de rupturas e culpas. Como personagem-símbolo das contradições de uma época de transição, ela é morta/negada por uma sociedade ofendida e contrariada em seus valores.

\section{JOÃO PAULO: A IMPOSSÍVEL CONTENSÃO (REALIDADE E FICÇÃO)}

O personagem João Paulo terá um papel fundamental na história, como escritor. O seu texto original funciona como um dos pólos da relação intertextual que mantém com o próprio romance da autora. Personificado como um anjo deslocado, aparece também como definitivo, talvez como Xangô ${ }^{23}$, na reflexão de Sofia:

Uma figura com um duplo, um anjo negro. Não Gabriel, talvez Xangô, com uma espada na mão. Um anjo de certa forma definitivo, como um verão que já aconteceu. (AS, p. 30)

João Paulo tem uma história complexa de trauma na infância, originada pela fixação que sentia pela mãe e que não foi superada na idade adulta. Esse problema 
interfere no seu comportamento, condi-cionando-o a confundir os planos da realidade e da ficção:

De olhos fechados, na rede, revê de repente, como uma vertigem, sua vida inteira. Cenas da infância no interior, onde nasceu, o sentimento de inferioridade diante dos colegas por causa de sua mãe, mulher muito bonita, mas com uma aura maldita porque, quando adolescente tinha sido prostituta e, mais tarde, tornou-se "rapariga" de um coronel do cacau. Seu pai era um soldado que mal conheceu, um caso de amor que sua mãe teve ainda quase menina. (AS, p. 40)

A condição atribuída à mãe de João Paulo merece uma explicação particular. Às vezes tende-se a considerar sinônimos os epítetos rapariga e prostituta, mas na verdade eles comportam uma distinção. Denomina-se rapariga a mulher jovem mantida por um homem casado, que exige fidelidade de sua protegida em troca dos favores sexuais exclusivos do homem que a mantém. Ambas as condições, tanto de rapariga como de prostituta, são formas de exploração e reificação da mulher como objeto sexual ao qual se dá um preço. Assim, a situação da mãe de João Paulo o humilhava, gerando sérios transtornos em seu comportamento, tanto enquanto criança, como já adulto.

$\mathrm{Na}$ fase adulta veio a se relacionar com uma mulher casada que não teve coragem de abandonar a família para viver com ele. Ao envolver-se com Sofia que efetivamente abandonou o marido, cometendo uma transgressão, ele desenvolve uma fixação pela protagonista e por sua história de vida, inspirando-se nela para compor a sua personagem Laura Luedi, a ex-miss que foi assassinada em um quarto de hotel:

- Uma ex-Miss, madura, sofisticada e perversa, é assassinada numa suíte de hotel de luxo em Copacabana. Este é o tema do meu romance - e quero todos os lances aventurescos a que o leitor tem direito. (AS, p. 134).

Antes de iniciar a escrita do livro, pensa em um pseudônimo e lhe ocorre Stingo, o mesmo do narrador do romance $A$ escolha de Sofia. A escrita do romance representava para o personagem um resgate de seu antigo desejo de ser escritor, uma forma de reencontro consigo mesmo e uma tentativa de se fazer compreender: - "Quero um livro que minha faxineira possa ler, de que possa gostar.” ( $A S$, p. 75). Seria um texto de leitura acessível para os diferentes segmentos sociais e culturais. Com esse objetivo, buscava eximir o futuro livro de complicações interpretativas, escrevendo-o em linguagem popular e fácil de ser lida e compreendida. Ele busca enfim um estilo mais direto e simples, com detalhes perfeitamente compreensíveis por pertencerem a um contexto familiar aos leitores. 
Entretanto, como às vezes acontece com os escritores que se baseiam na realidade para compor a sua ficção, João Paulo apropria-se do fato de vida de uma outra personagem para estabelecer uma moral ou um juízo de valor. A partir de um situação vivida na infância e relatada por Sofia, que ele rememora, cria então Laura Luedi, que será seduzida ou violentada por um tio, e que recalcará este acontecimento, sentindo medo e atração por este primeiro homem, até que ele se suicide.

O fato de reproduzir fielmente a trajetória de Sofia já é um indício de seu desequilíbrio e da fixação que sentia pela protagonista, que fica, aliás, horrorizada, quando descobre que o episódio de sua vida foi usado pelo escritor: "Ela está muda, com uma expressão de horror. De repente, brada: - Mas você teve a coragem de usar isso, uma coisa que, afinal, em toda a minha vida só contei a vocêl' $(A S$, p. 76$)$.

A reminiscência que o escritor tem do poema de Baudelaire, intitulado Spleen, que exprime o tédio de tudo, ${ }^{24}$ indica também que João Paulo não lidava bem com os seus sentimentos:

Sou como o rei sombrio de um país chuvoso, Rico, mas incapaz, moço e no entanto idoso, Que, desprezando do vassalo a cortesia, Entre seus cães e os outros bichos se entedia. Nada o pode alegrar, nem caça nem falcão, Nem seu povo a morrer defronte do balcão. Do jogral favorito a estrofe irreverente Não mais desfranze o cenho deste cruel doente. Em tumba se transforma o seu florido leito, $\mathrm{E}$ as aias, que acham todo príncipe perfeito, Não sabem mais que traje erótico vestir Para fazer esse esqueleto enfim sorrir.

O sábio que ouro lhe fabrica desconhece Como extirpar-lhe ao ser a parte que apodrece, E nem nos tais banhos de sangue dos romanos, De que se lembram na velhice os soberanos, Pôde dar vida a esta carcaça, onde, em filetes, Em vez de sangue flui a verde água do Letes.

Já no primeiro verso é patente a proximidade do poema com o estado de espírito do personagem. Ele possui talento, idéias e vocação para a escrita, entretanto não consegue se desvincular dos traumas do seu passado, consumindo-se em conflitos 
interiores. A expressão "tédio de tudo", o spleen, é adequada para descrever a alma atormentada e doentia de João Paulo. Nada mais lhe desperta a vontade de existir. Esta é a verdadeira identidade do homem de meia idade que faz relativo sucesso entre as mulheres com seu rosto bonito e gasto. "E as aias, que acham todo príncipe perfeito,/ não sabem mais que traje erótico vestir / Para fazer este esqueleto enfim sorrir."

A escrita do livro tinha a função catártica de atenuar esse conflito interior, originário do sentimento de fascínio e repulsa que sentia pela mãe. Este problema sempre vinha à tona diante da efemeridade de seus relacionamentos afetivos, assim explicados:

Sempre houve nele, admite também, um potencial inesgotável e semi-adormecido do ódio contra as mulheres. Com certeza uma ambivalência do relaciona-mento com sua mãe, que adorava e detestava, ao mesmo tempo. Quando existe, com alguma mulher, uma possibi-lidade de relação mais profunda, então o ódio vem à tona. (AS, p. 74)

Este ódio de alguma forma se manifesta por Sofia, quando ele resolve recriar a história que ela lhe confiou como um segredo. O sentimento que João Paulo nutre pela amiga e por sua história também está associado à sua atração por mulheres fortes que transgrediram os padrões estabelecidos. Esta tendência é responsável pelo seu interesse por personalidades históricas femininas, como se observa na citação de passagens da vida de Maria Quitéria: ${ }^{25}$

Quando falou de sua vontade de se alistar, o pai lhe disse: “As mulheres não nasceram para a guerra e sim para tecerem, bordarem e fazerem trabalhos de casa.” (AS, p. 87).

O discurso restritivo do pai da heroína nada mais é do que a enumeração das funções historicamente atribuídas à mulher. $\mathrm{O}$ fato de Maria Quitéria ter transgredido uma ordem preestabelecida aguça em João Paulo a fantasia de conhecê-la pessoalmente. Ele também identifica a personagem histórica com Sofia, devido à semelhança de caráter das duas, no sentido de não se dobrarem ao modelo feminino. Para João Paulo, ambas são bem diferentes de Alina, que não conseguiu se desvencilhar da familia para acompanhá-lo e, assim, aguçou o seu sentimento de rejeição pela mulheres frágeis.

A história previsível não atraía o virtual escritor, que buscava enredos mais emocionantes, protagonizados por mulheres fortes, que viveram situações contrárias às normas comuns de comportamento. Ele incorpora, então, a seu texto, a história de incesto vivenciada por Sofia. 
Esse tema é recorrente na ficção de Sônia Coutinho. No conto "Na penumbra”26, a personagem recalca um sentimento de atração pelo pai, o que só fica claro ao final do conto. A protagonista revela ao amante que viveu uma situação de incesto quando menina. No decorrer da narrativa, a dúvida sobre o ter acontecido ou não o incesto se instala. E ela é aprofundada ao final do conto:

Quando percebe que ele dorme profundamente, a mulher desprende-se devagarinho do seu abraço e fica observando-o. Depois se aproxima, beija-o de leve nos lábios. Com uma das mãos, acaricia-lhe o rosto, com a outra vai explorando o fundo poço do seu próprio sexo, numa lenta exploração de prazer.

- Papai, papai - ela murmura, olhando para o homem adormecido. (VL, p. 35).

O impacto do final do conto esclarece a patologia do caso amoroso, em abordagem que desperta e mantém a atenção do leitor. ${ }^{27}$

A personagem criada por João Paulo, a partir da história segredada por Sofia, vive um caso psicanalítico, o trauma de ter sido seduzida ou violentada por um tio. Segundo o personagem Fernando, João Paulo prefere considerar que a sua personagem é um caso sociológico:

Seus traumas, sob certos aspectos vinham dos limites impostos às mulheres de sua geração, dos preconceitos a que estavam submetidas. Por exemplo, a idéia generalizada de que sexo, em quaisquer circunstância, era pecado e deixava a mulher impura. No fundo de sua cabeça de anos 50, ela achava que tinha pecado gravemente, que estava em pecado mortal por ter sido seduzida ou estuprada. (AS, p. 135).

Trata-se de uma referência à culpa que às vezes se atribui à mulher, mesmo que tenha sido vítima de uma situação de violência sexual. A educação conservadora a condiciona a se sentir culpada, por ter supostamente contribuído de alguma forma para o desencadeamento do ato. É dessa maneira que João Paulo representa sua personagem Laura Luedi, como se observa em seu diálogo com Fernando:

- Para ela, embora vítima, sua culpa era igual, ou talvez maior que a do tio, por ser mulher. Então não denunciou o tio, não teve coragem de contar aquilo a ninguém, guardou segredo em torno do que havia acontecido, durante o resto da infância e a adolescência inteira. Simplesmente, curtiu sua culpa, seu medo, seu nojo do tio e sua atração por ele, ao longo de intermináveis aulas de catecismo a que era obrigada a assistir na escola. (AS, p. 135). 
João Paulo/Stingo procura construir a sua narrativa se apropriando de fatos que fizeram parte de sua vida, ou de outros, em busca de um enredo sedutor e inusitado. No decorrer da trama, a história de Laura Luedi flui paralelamente à trajetória de Sofia, tornando-se seu duplo. Para Stingo ambas se confundem:

[...] Laura Luedi, loura e lindíssima, como nos tempos em que quase foi Miss Universo. Uma boneca, mulher criança, cujo rosto, de repente, sob seu olhar perplexo, transforma-se agora em outro, moreno, com traços de índia, cabelo liso e negro e batom muito vermelho. É Sofia que ele vê desfilar, no lugar de Laura. (AS, p. 42).

O processo de enlouquecimento de João Paulo é pontuado no romance a partir da confusão que há entre as personagens Laura Luedi e Sofia. E caminha para o desfecho, sem desvios. Sofia percebe a perturbação do amigo, quando o reencontra:

- Estou achando você meio abatido, meio esquisito, o que há?

- Não ando bom da cabeça - ele responde - Antes de sair do Rio estava à beira de um colapso. E ainda não consegui relaxar. (AS, p. 50).

Para tentar dar um sentido a sua vida, João Paulo tenta escapar do esquema sufocante das redações de jornal do Rio para se reencontrar através da escrita do seu livro. Não é à toa que o tema do romance é o passado, focalizando uma miss dos anos 50 , assunto nostálgico, que revela uma ansiosa busca de sentido em passado relativamente distante quando o futuro parecia incerto. Como o bom senso de João Paulo o abandonava, ele é acometido de um sentimento de temor à morte, fonte de angústia do ser, que ele vivencia, por exemplo, no almoço com os tios idosos:

O almoço tem um gosto inevitável de velhice e morte, assuntos constantes do tio, que fala disso como quem protesta ou pede socorro. Não é justo, parece pensar, deve haver alguma coisa fora do lugar. Não é possível que isso aconteça com as pessoas, envelhecerem e morrerem. É uma peça terrível que estão pregando só a ele. (AS, p. 70).

João Paulo apresenta sinais claros de depressão, agravados pela conversa dos tios que, devido à idade avançada, se preocupam constantemente com a morte. $\mathrm{O}$ próprio projeto do livro lhe parece sem sentido. Deixando-se levar pela ficção, resolve comprar uma arma. E justifica esse ato: a necessidade de conhecer a arma para melhor desenvolver a descrição do assassinato de sua personagem Laura Luedi. O personagem-escritor chega a pedir um conselho a Moacir, repórter policial: 
Escute, Moacir, estou escrevendo um romance. Sim, um romance. Nele, há um crime. Alguém dá três tiros numa mulher, numa suíte de hotel de luxo, em Copacabana. Então, preciso que você me dê algumas dicas sobre armas, porque não entendo do assunto. Qual seria a arma pequena com que se poderia matar uma mulher, sem muito barulho, sem muito sangue? (AS, p. 72).

O personagem-escritor parece estar se preparando para escrever o epílogo do romance. Mas, na verdade, está premeditando um outro crime. João Paulo já em estado de delírio, e sem saber exatamente o que pretendia com a escrita do romance, arma a sua história romanesca como se fosse a história de Sofia. Parece ter se deixado enlouquecer para, amparado pela loucura, vingar-se da mãe, que o expôs a diversas situações de humilhação. De fato, ele atualiza seu trauma ao se relacionar com qualquer mulher. Sofia torna-se, então, objeto de sua vingança devido à fixação que ele possuía pela sua história, pontilhada de transgressões, desde o episódio do incesto até o abandono do marido e filhas. Enfim, João Paulo percebe o seu processo de enlouquecimento e o aceita de forma passiva:

Na cama tentando dormir, conclui: enlouquecer é muito mais fácil do que jamais imaginou. A loucura, pensa, com uma lucidez dividida, que lhe permite ver a si mesmo de uma distância infinita, pode ser triste e incômoda, mas não é, de forma alguma, insuportável. Pode-se perfeitamente enlouquecer e continuar vivendo, como todo mundo - ou quase. (AS, p. 106).

A escrita do livro cumpre uma função liberatória e representa para João Paulo um elo com o mundo exterior, que atenua a sua clausura e isolamento. Isso fica claro no diálogo com Fernando, quando ele se refere a sua protagonista, descrevendo a sua personalidade:

- Tornou-se bloqueada para sexo, não tinha prazer nenhum, sentia pavor dos homens. Só mais tarde, depois de muitos anos de análise, empreendeu uma espécie de descoberta do seu prazer e, nesse processo partiu para os garotos. (AS, p. 135).

No entanto, João Paulo tem certeza de que não concluirá o seu livro. Ele não tem mais motivação para desenvolver o projeto tão importante, que o fizera abrir mão de toda uma vida para poder a ele dedicar-se:

Nenhum projeto, pensa, nada lhe interessa mais. Nem o romance que pretendia escrever e o trouxe para cá, mas - a certeza lhe vem como uma punhalada - que não terminará nunca. (AS, p. 70-71). 
A trajetória do personagem-escritor se caracteriza finalmente por esta dificuldade e incapacidade de concluir o livro ou qualquer outro projeto. A sua dificuldade de criar ficcionalmente faz com que ele se prenda demasiadamente à realidade de Sofia, que lhe serve de inspiração. A similaridade das situações vividas pelas personagens Laura Luedi e Sofia mostra que João Paulo extrapolou o limite entre realidade e ficção, ao confundir o plano da sua vivência com o da sua criação textual.

D.C. Muecke destaca que o texto irônico deixa aberta a questão dos seus significados, servindo-se de coincidências e de ambigüidades, de modo a ativar múltiplas interpretações. ${ }^{28} \mathrm{Em}$ Atire em Sofia, a técnica da história encaixada dentro da história principal acentua o efeito irônico, pois a coincidência e a ambigüidade das situações vividas pelas duas personagens abrem espaço ao leitor para diferentes interpretações a partir dos fatos narrados ou sugeridos. A cena do assassinato de Sofia é teatral e pode ser vista como um exemplo de ironia dramática, conforme a define D. C. Muecke. ${ }^{29}$ A aproximação afetiva de João Paulo em vez de trazer algo positivo a Sofia, na verdade representará, sem que ela saiba, a sua ruína. A personagem caminha para seu destino fatal, envolvida numa trama já prefigurada nas laudas escritas por João Paulo. Ironicamente, a amiga que o atraía e o inspirou, é escolhida por ele para viver a cena final, em que morre assassinada.

No final do romance, os fatos obscuros são parcialmente esclarecidos através da colagem de informações de diferentes fontes. A empregada do personagem Fernando comenta, em linguagem cifrada, alguma coisa vista no terreiro de candomblé:

- Seu Fernando, aquele amigo seu apareceu esta semana lá na ilha, no terreiro dos Egungún, entre os Babá Egún. Estava debaixo das tiras de pano. (AS, p. 149).

A revelação inesperada da empregada surpreende Fernando e o leitor. $\mathrm{O}$ aparecimento de João Paulo, enrolado em tiras, no terreiro dos Egungún, significa que ele estaria morto. Do ponto de vista da ficção, é uma saída que se sustenta através da crença de que os mortos retornam e dão mostras de que estão num outro plano, que não o terreno. No entanto, para o leitor fica apenas de concreto o desaparecimento do personagem.

João Paulo escreve a parte final do seu romance já em estado de loucura, confundindo sua ficção com a vida de Sofia. Há uma confluência dos dois planos narrativos. E os finais convergem num só ponto, unificando as histórias paralelas. A loucura do personagem-escritor leva-o a confundir o plano da realidade, em que se insere sua vivência pessoal e a presença de Sofia, com a sua ficção. Ele projeta sobre a figura de 
Sofia a imagem de Laura Luedi, que é criação ficcional sua, realizando também nesta a sua pulsão de morte. João Paulo finaliza o romance com a morte de Sofia:

- Já sei quem matou Laura Luedi.

- Quem foi? - ela pergunta.

- Foi o jornalista, João Paulo - ele diz.

(AS, p. 176).

A atitude de João Paulo é passional. Observa-se que ele empreendeu um discurso amoroso antes de dar a Sofia o fim que estava previsto para Laura Luedi. Ele faz uma espécie de declaração de amor de despedida, como a reduplicar o mesmo sentimento de atração e repulsa que ele sentia pela mãe:

- Amo você. Amo esse lado todo penumbra, essa sombra interior que vai além da sensualidade mesma. Amo esse seu requinte sofrido, esse sopro de Holanda e Companhia das Índias, amo sua raiz ibérica também, o que há em você de nostalgia da siesta. E amo, ainda, seu lado de negra, ou de índia, esse lado instintivo. Amo sua solidão, mas ainda assim exposta ao vento, à amplidão. Você na praia, banhada de dourado antigo, raios de sol como volutas barrocas. (AS, p. 175).

O discurso erótico/amoroso desarma Sofia, que não percebe qualquer indício das intenções de João Paulo. No entanto, a declaração fora de hora e de tom causa-lhe estranhamento. A cena culmina no assassinato de Sofia, tantas vezes anunciado por João Paulo, sob a forma de ficção, através da personagem Laura Luedi:

Dezenas de mãos apertam o gatilho, três tiros surdos ecoaram no quarto.

Num último gesto, Sofia tenta puxar os lençóis, como se quisesse cobrir-se. (AS, p. 177).

Este desfecho revela o extremo a que chega a loucura de João Paulo. Sua personalidade doentia, decorrente de um problema mal resolvido na infância, o horror que sentia pela mãe, transforma-se, afinal, numa forma extrema de misoginia. ${ }^{30}$ Mas a sua atitude torna-se coletiva (dezenas de mãos apertam o gatilho), representando um ato da sociedade conservadora que repudia e condena a personagem transgressora.

João Paulo determina a morte de Laura Luedi, na sua narrativa, assim como mata Sofia, que lhe servia de modelo e inspiração. A protagonista morre porque João Paulo determinou a sua morte, através da trajetória de Laura Luedi. Dessa forma, a coincidência dos planos narrativos se completa, pois o fim de Laura Luedi significa a morte de Sofia.

\section{SOR}




\section{NOTAS}

${ }^{1}$ COUTINHO, Sônia. Atire em Sofia. Rio de Janeiro: Rocco, 1989. Nas próximas referências e citações serão utilizadas as inicias $A S$, seguidas do número da página.

${ }^{2}$ KOLBENSCHLAG, Madonna. Adeus, Bela Adormecida: A revisão do papel da mulher nos dias de hoje. 2.ed. São Paulo: Saraiva, 1991, p. 258. A respeito da noção do princípio feminino, a autora comenta: "As raízes gnósticas de algumas dessas revelações místicas sugerem que a "revisão” da noção patriarcal de Deus é tão antiga quanto o próprio cristianismo. Em vez de um Deus monístico e masculino, muitos dos textos dos " evangelhos" gnósticos - O livro secreto de João, O evangelho secreto dos hebreus, O evangelho de Tomás, $\mathrm{O}$ evangelho de Filipe, além de outros - descrevem Deus como um ser diádico que consiste em elementos tanto femininos como masculinos. [...] O fato de essas escrituras heréticas ou heterodoxas terem sido suprimidas nos primórdios da Igreja está relacionado à supressão eclesiástica das mulheres, mais do que uma exegese dogmática”. Cf. Op. cit., p. 258-9.

${ }^{3}$ STYRON, William. A escolha de Sofia. 3.ed. Trad. Vera Neves Pedroso. Rio de Janeiro: Record, 1979.

${ }^{4}$ MORGADO, Belkis. A solidão da mulher bem-casada. 3.ed. Rio de Janeiro: José Olympio. 1986, p. 6.

${ }^{5}$ COUTINHO, Sônia. Uma certa felicidade. 2.ed. Rio de Janeiro: Rocco, 1994, p. 15.

${ }^{6}$ Segundo Laplanche \& Pontalis, "o sentimento de culpa pode designar um estado afectivo consecutivo a um acto que o indivíduo considera repreensível, e a razão invocada pode aliás ser mais ou menos apropriada (remorso de um criminoso ou auto-recriminação aparentemente absurdas), ou ainda um sentimento difuso de indignidade pessoal sem relação com um acto determinado de que o indivíduo se acuse”. Cf. LAPLANCHE, J.L. \& PONTALIS, J-B. Vocabulário da Psicanálise. 10. ed. São Paulo: Martins Fontes, 1988, p. 614.

${ }^{7}$ CHAUÍ, Marilena. Convite à Filosofia. São Paulo: Ática, 1994, p. 364.

${ }^{8}$ Nelly Novaes Coelho comenta que, em Sônia Coutinho, "essa nova reação à problemática básica do 'eterno feminino' (a realização da mulher no Amor), soma-se aqui à nova linguagem narrativa que se divulga na ficção a partir dos anos 60, e que nos revela uma nova consciência da tarefa do escritor”. Cf. COELHO, Nelly Novaes. À guisa de posfácio. In: STEIN, Edla van (Org.). O conto da mulher brasileira. 2.ed. São Paulo: Vertente, 1978, p. 248.

${ }^{9}$ LISPECTOR, Clarice. A paixão segundo GH. 15.ed. Rio de Janeiro: Francisco Alves, 1991. Na citação de trechos, serão utilizadas as iniciais PSGH, seguidas do número da página.

${ }^{10}$ É interessante lembrar que Lilith é um mito arcaico, seguramente anterior, na redação jeovística da Bỉblia, ao mito de Eva. Segundo o mito, Lilith teria sido a primeira companheira de Adão. Lilith entra no mito já como uma figura demoníaca, de saliva e sangue, um verdadeiro espírito deixado em estado informe por Deus. Cf. SICUTERI, Roberto apudPAIVA, Vera. Evas, Marias, Liliths... as voltas do feminino. 2.ed. São Paulo: Brasiliense, 1989, p. 61.

${ }^{11}$ Yansan ou Oya - princesa real da cidade de Irá, em Nupe, que veio a ser esposa de Shangô, a quem o rio Níger é dedicado. Daí esse rio ser chamado Odo Oya. Viveu por volta de 1450 a. C. Deusa dos ventos, dos raios e dos mortos. Controla o IGBALE (casa dos mortos). Reputada ter sido a maior guerreira do Império Yorubano. Conhecida no Brasil por Yansan (senhora da tarde). Cf. FONSECA JÚNIOR, Eduardo. Dicionário Yorubá (nagô) Português. 2.ed. Rio de Janeiro: Civilização Brasileira, 1993, p. 333.

${ }^{12}$ CHAUÍ, Marilena. Op. cit., p. 365.

${ }^{13}$ Mito grego, Cérbero é o cão monstruoso de várias cabeças e cauda de serpente que guarda a entrada do inferno. Cf. GUIMARÃES, Ruth. Dicionário de mitologia grega. São Paulo: Cultrix, 1988, p. 103. Cérbero é o Cão de Hades que "simboliza o terror da morte [...] os próprios infernos e o inferno interior de cada ser humano.[...] Para derrotá-lo, não se pode contar senão consigo mesmo”. Cf. CHEVALIER, Jean \& GHEERBRANT. Alain. Dicionário de símbolos. 2.ed. Rio de Janeiro: José Olympio, 1989, p. 422.

${ }^{14}$ Segundo o autor, os tratados jurídicos, inicialmente manuais de inquisidores, "confirmam olugar conferido à mulher no delito de feitiçaria. Mas esses tratados só aparecem no final do século XV, enquanto o mito demonológico - a crença na existência de uma seita de feiticeiros voltados ao culto do Diabo - se constitui mesmo no final do século 
XIV, desencadeando uma repressão cada vez mais severa." Cf. SALLMANN, Jean-Michel. Feiticeira. In: DAVIS, Natalie Zemon \& FARGE, Arlette (dir.). História das mulheres: Do Renascimento à Idade Moderna. Porto: Edições Afrontamento; São Paulo: Ebradil, 1991, v. 3, p. 518.

${ }^{15}$ Id., Ibid., p. 532.

${ }^{16}$ Id., Ibid., p. 529.

${ }^{17}$ ARAÚJO, Emanuel. A arte da sedução: sexualidade feminina na colônia. In: PRIORE, Mary del. História das Mulheres no Brasil. São Paulo: Contexto, 1997, p. 48.

${ }^{18}$ Id., Ibid, p. 49.

${ }^{19}$ Id., Ibid., p. 461.

${ }^{20}$ CHEVALIER, Jean \& GHEERBRANT, Alain. Op. cit., p. 462.

${ }^{21}$ CHAUÍ, Marilena. Op. cit., p. 366.

${ }^{22}$ A clivagem do ego é uma expressão usada por Freud que indica a coexistência, no ego, de duas atitudes psíquicas para com a realidade exterior na medida em que esta vem contrariar uma exigência pulsional: uma tem em conta a realidade, a outra nega a realidade em causa e coloca em seu lugar um produto do desejo. Estas duas atitudes persistem lado a lado sem se influenciarem reciprocamente. Cf. LAPLANCHE, J. \& PONTALIS, J-B. Op. cit., p. 101.

${ }^{23}$ Nos centros umbandistas do Brasil, Xangô é a divindade que rege os relâmpagos, raios, coriscos, tempestades. Propicia a paz, a sabedoria, a justiça, a prosperidade. Cf. DONATO, Hernâni. Dicionário de mitologia. São Paulo: Cultrix, 1973, p. 260.

${ }^{24}$ BAUDELAIRE, Charles. As flores do mal. 5.ed. Rio de Janeiro: Nova Fronteira, 1985, p. 295.

${ }^{25}$ Maria Quitéria de Jesus (1792-1853), heroína baiana, alistou-se como o Soldado Medeiros, para lutar na guerra pela independência na Bahia. Participou do Batalhão de Infantaria Voluntários do Príncipe, ou Batalhão dos Periquitos, sob o comando do Coronel José de Barros Falcão Lacerda. Lutou nas Batalhas de Pirajá e de Cachoeira. Foi condecorada com a insígnia de Cavaleiro da Ordem Imperial do Cruzeiro. Cf. HOLANDA, Sérgio Buarque de (Dir). Grandes personagens da nossa bistória. São Paulo: Abril Cultural, 1972, v. 2, p. 381.

${ }^{26}$ COUTINHO, Sônia. Os venenos de Lucrécia. São Paulo: Ática, 1978, p. 28-35.

${ }^{27} \mathrm{O}$ tema do incesto, ou a simples sugestão, sem afirmá-lo ou negá-lo, está presente também no romance $O$ caso Alice, analisado no terceiro capítulo, em que a personagem é seduzida pelo padrasto quando menina.

${ }^{28}$ Id. Ibid., p. 48.

${ }^{29}$ Partindo do conceito clássico de ironia como discurso que "diz uma coisa mas significa outra", o autor delimita suas diversas nuanças e aplicações na literatura moderna. Entre estas destaca a ironia dramática como aquela em que um personagem é tomado por uma espécie de "cegueira" e caminha, sem saber, para um destino prefigurado, que é de conhecimento da platéia. Cf. MUECKE, D. C. Ironia e o irônico. São Paulo: Perspectiva, 1995, p. 25, 33 e 87.

${ }^{30}$ Segundo Madonna Kolbenschlag, "a misoginia tem raízes profundas em nossa cultura e vem à tona da forma mais brutal quando emergem o poder e a autonomia femininas. Acontece não só com os homens, mas com as mulheres também.” Cf. KOLBENSCHLAG, Madonna. Op. cit., p. 153.

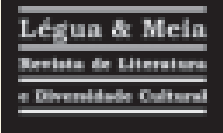

PATRÍCIO, Rosana Ribeiro. Uma imagem de mulher no romance Atire em Sofia, de Sonia Coutinho. Légua \& Meia: Revista de Literatura e Diversidade Cultural. Feira de Santana, UEFS, $\mathrm{n}^{\circ} 1,2002$, p. 252-276.

Rosana Maria Ribeiro Patrício é Professora da UEFS. Licenciada em Letras pela UFBA, Mestre pela UFPB e Doutora pela USP. Principais publicações: Imagens de mulher em Gabriela de Jorge Amado (1999), Rotas e imagens: Literatura e outras viagens (co-autora, 2000). É membro do conselho editorial de Iararana. 


\section{CRITÉRIOS PARA PUBLICAÇÃO}

Trabalhos para publicação na revista Légua \& meia poderão ser encaminhados aos editores, observando-se o seguinte:

1. Envio do texto em disquete, corrigido e revisado, na forma a ser publicada.

2. Cópia em papel para que seja submetida a parecer do Conselho Editorial.

3. Dados e créditos do Autor. Exemplo: LuCAS SEverino é Professor Associado da UEPB. Graduado em Letras pela Unicamp, Mestre pela UEFS, Doutor pela USP, Pós-Doutorado em Havard. Publicou, dentre outros livros, Novos teoremas (1997) e Contradições do cânone (2000). É crítico de teatro e editor da revista Interseçoes.

4. Citações extensas, ou com mais de quatro linhas, podem vir separadas do copo do texto por uma linha em branco antes e outras depois; citações menores são marcadas através de aspas e dispostas no próprio corpo do texto.

5. Evite o uso de itálico para indicar citação, reservando este recurso para destacar palavras e expressões ou para marcar títulos de livros e outras publicaşões.

6. Notas de pé-de-página devem ser limitadas ao estritamente necessário, procurando-se inserir a informação no próprio curso do texto. Para evitar sobrecarregar o pé-de-página com informações, as referências bibliográficas devem ser feitas pelo chamado sistema "Autor-data", constando entre parênteses, no corpo do texto, o Sobrenome do Autor em caixa baixa, seguido do ano da publicação e do número das páginas citadas. Exemplo: (Candido, 1999: 127-8).
7. A bibliografia ou as referências bibliográficas devem constar no final do trabalho, observando-se a seguinte sistemática, tomada como exemplo:

ANDRADE, Mário (1972). O empalhador de passarinho. 3 ed., São Paulo, Martins.

FISHMAN, Charles (1999a). Sociologia do pensar. Rio de Janeiro, Eldorado.

FISHMAN, Charles (1999b). Identidades paralelas: a crise do pensamento crítico. Rio de Janeiro, Eldorado.

8. Embora a norma da ABNT adote um alinhamento uniforme para as entradas bibliográficas, a revista Légua \& meia prefere destacar uma nova entrada de Autor com o alinhamento da primeira linha diferenciado, para facilitar o processamento da informação, conforme o exemplo do item anterior.

9. Como no Brasil os autores são identificados principalmente pelo nome próprio, recomenda-se evitar, na bibliografia, a abreviação do mesmo pela inicial seguida de ponto. (Exemplo: Ao invés de usar SANTOS, M., prefira SANTOS, Milton.)

10. Ao listar várias obras do mesmo autor, prefira repetir o nome do mesmo, ao invés de substituí-lo por travessão. Quando processada no computador, a entrada bibliográfica é identificada e ordenada pelos caracteres do nome; deste modo, as entradas precedidas de travessão podem ser lidas como outro nome e remetidas para outro lugar da bibliografia, fora da seqüência das obras do autor. 


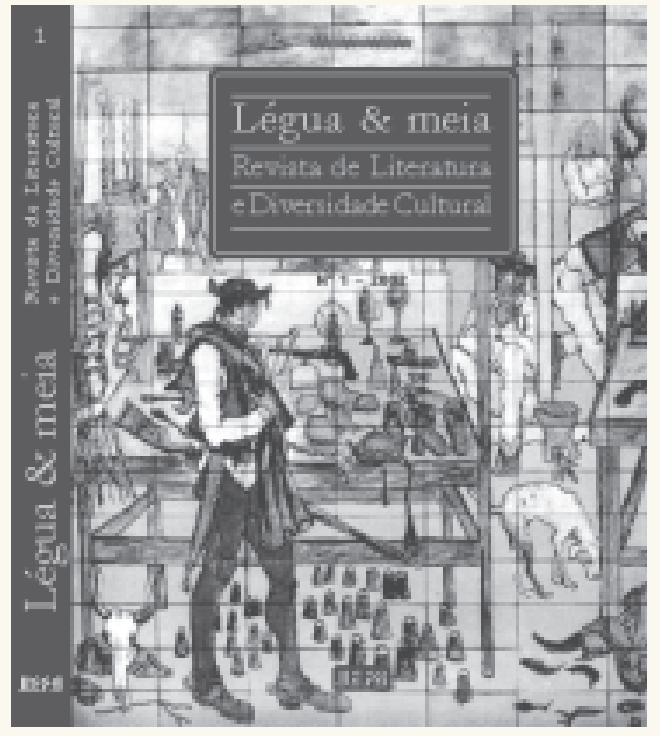

As publicações do

Programa de Pós-GRAduAÇÃo

EM LITERATURA E DIVERSIDADE CULTURAL, em cujo âmbito a revista

Légua \& meia está inserida,

foram iniciadas no ano 2000

com o volume coletivo

\section{Rotas \& Imagens:}

Literatura e outras viagens.

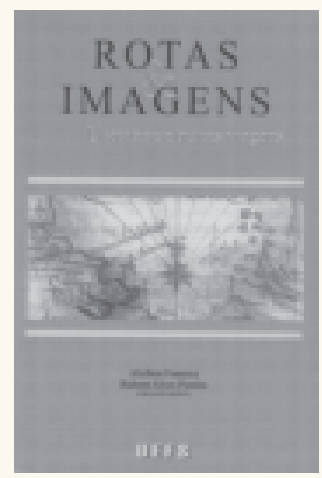

Rotas \& Imagens, volume organizado por Aleilton Fonseca e Rubens Alves Pereira, reúne vinte trabalhos de estudiosos da UEFS e de outras instituições, tratando de Literatura e outras séries culturais.

A Estética da Sinceridade \& outros ensaios traz uma seleção de textos ensaísticos do poeta Antonio Brasileiro, marcados pela irreverência e pela liberdade criadora.

A Unidade Primodial da Lírica Moderna, de Roberval

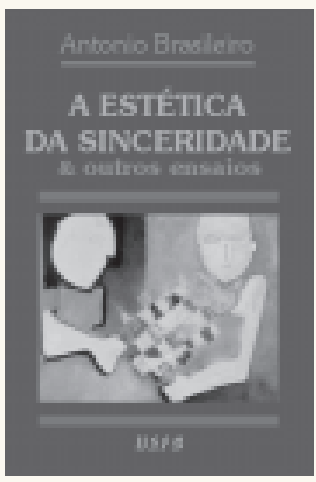
Pereyr, junta a pesquisa à intuição de um poeta, resultando num texto que retoma os estudos sobre a teoria do verso na modernidade. 

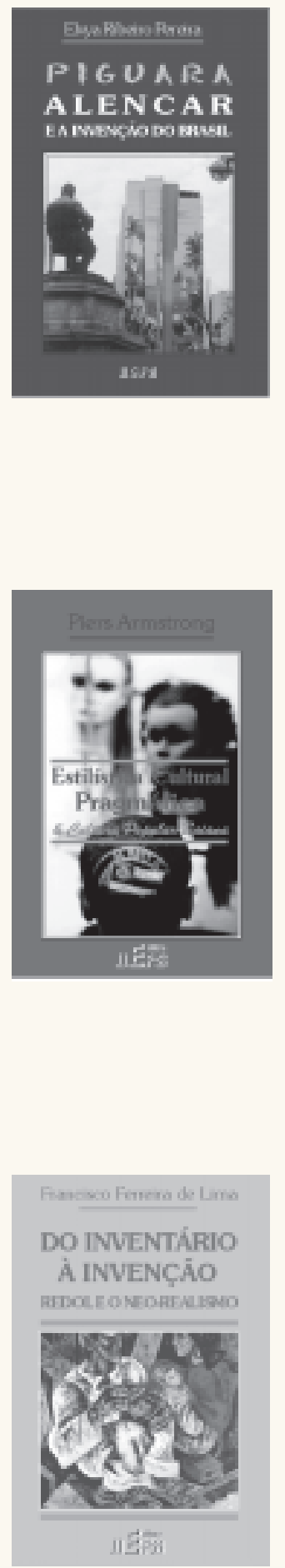

Piguara: Alencar e a invenção do Brasil, de Elvya Ribeiro Pereira, é um livro instigante e de interesse atual, centrado nos problemas identitários surgidos no século XIX, com o desmantelo do colonialismo nos países americanos.

Aloísio Resende reúne trabaIhos de pesquisadores de documentos literários a uma mostra de textos de um esquecido poeta de Feira de Santana. O volume foi organizado por Ana Angélica Vergne, Cristiane Porto e Lucidalva Assunção.

\section{Estilística Cultural Pragmáti-}

ca, de Piers Armstrong, aborda aspectos da cultura popular da Bahia, sob as lentes perquiridoras de quem chega trazendo malas e bagagens de uma outra cultura.

Gil Vicente, de Theresa AbeIha Alves, retoma o poeta e dramaturgo português sob o signo da derrisão, buscando apreender o sentido do texto vicentino como crítica ao contexto, através das categorias do cômico.

Do Inventário à Invenção é um estudo de Francisco Ferreira de Lima sobre o Neo-Realismo português, tomando como ponto nuclear o romance de Alves Redol, autor pioneiro do realismo socialista no seu país.
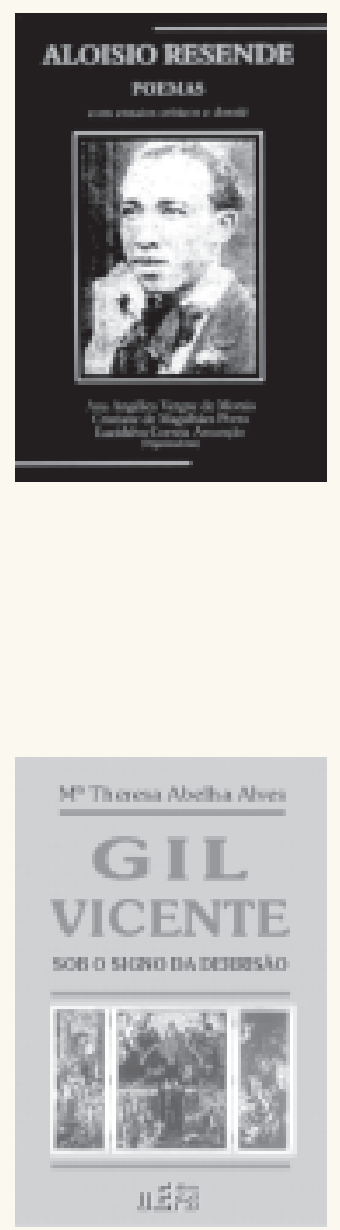
Este primeiro número de

Légua \& meia: Revista de literatura e diversidade cultural foi projetado e artefinalizado por Cid Seixas.

A reprodução do Painel de Lênio Braga

obedeceu a projeto do pintor Juracy Dórea, autor do ensaio fotográfico, com ensaio-texto de Rubens Alves Pereira..

A impressão foi executada na cidade de Feira de Santana, Bahia, por

GRAFINORTE

Recograf Comécio, Serviços e RepresentaÇÕes LtdDa.

Av. Banco do Nordeste - Centro Industrial de Subaé - 44.062-510

疋 (75) 622-0444 